\title{
Making The Case For The Creation Of An Academic Honesty And Integrity Culture In Higher Education: Reflections And Suggestions For Reducing The Rise In Student Cheating
}

Frank J. Cavico, Nova Southeastern University, USA Bahaudin G. Mujtaba, Nova Southeastern University, USA

\begin{abstract}
Using an example from the work of one university in the United States, this case is principally an essay of reflections, thoughts, questions, and suggestions for the creation of an academic honesty and integrity culture in higher education institutions. The authors provide their thoughts and insights from their combined 30 years of teaching and administration experiences regarding this important and challenging academic area. The authors were recently involved in the revision of their business school's academic honesty policy as well as in their school's yearly conference for all faculty members - full-time and adjunct - in which the topic of academic honesty was the primary academic component. This article is not intended to be a research type article, though some current research on academic honesty will be presented, neither is it intended to be a detailed explication of the authors' school's academic honesty policy, nor a "how to" article when it comes to a school's developing and implementing academic honesty policies and procedures. Rather, as the word "Reflections" in the article's title indicates, this paper is based on the knowledge gained by the authors in their school's revision of its policy, their participation in the conference and the presentations therein, as well as the authors' own experiences from teaching management, business law, and business ethics courses for many years. The authors hope that the issues they raise, the insights they obtained, and the recommendations and suggestions they make will be helpful to their colleagues in academia in establishing a culture of academic honesty and integrity at their schools.
\end{abstract}

Keywords: cheating, plagiarism, academic honesty, higher education, assessment of education, faculty conference, student monitoring

\section{THE IMPORTANCE OF AN ACADEMIC HONESTY CULTURE}

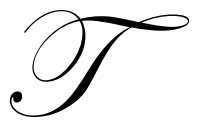

he foundation to the academic honesty policy is the school's commitment to the values of ethics, integrity, and honesty, The H. Wayne Huizenga School of Business and Entrepreneurship's first precept in its Guiding Principles and Philosophy is that we are driven to "Conduct all our academic affairs with integrity." Accordingly, the school must clearly communicate the institution's expectations regarding ethics, integrity, and academic honesty, so the administrators must take academic misconduct very seriously. One goal is to link academic honesty to personal, business, and professional success. This goal is similar to the objective of the school's law and ethics courses; that is, to link legal and ethical behavior with personal and business success. It is imperative that a link be established between academic honesty and ethics and integrity and long-term personal, business, and career success. The intent of the academic honesty policy is not merely to be the "police" of academic violations, but rather to create a culture and climate at the school that emphasizes, and is more conducive to, academic honesty. Yet, when the faculty and administration are the "police," they must make sure that academic 
misconduct is proceeded against pursuant to the academic honesty code in a fair and consistent manner. As such, the faculty and administration must avoid any enforcements that appear arbitrary and capricious or inequitable and unjust. Another critical point to make is that when the faculty does uphold and enforce policy, the faculty must have the complete and total support of their faculty colleagues, the program offices, the administration, and particularly the deans of the school.

The authors of this essay do make an assumption; that is, that most people, including the students, of course, are moral and ethical. Thus, they want to do the "right things" and make the "right" decisions. However, the authors are very well cognizant of the old "Cold War" saying: "Trust but verify."

\section{THE WIDESPREAD CULTURE OF CHEATING}

In today's school environment, there has been an influx of reports and news concerning student cheating and dishonesty (McGill, 2008). Having an environment where cheating is perceived as a necessity is not a good form of conditioning and preparing students for the "real world" (Mujtaba and Preziosi, 2006). Young students eventually end up running schools, governments and corporations, where cheating, as clearly evidenced by the economic crisis of 2008-2009, is not productive for society. As such, innovative and new measures must be taken to reduce cheating among students by showing them a better way and also by removing their need for resorting to such tactics. Fortunately, there are dedicated faculty members that attempt to reduce dishonesty and cheating in the classroom by being persistent and innovative. Innovative techniques are important and emphasized because there are no "cookie cutter" approaches to stop all practices of cheating.

While cheating is not necessarily created at the college level, the cultures of institutions might further reinforce it. On April 29, 2004, ABC's (American Broadcasting Corporation) Prime Time had a segment on cheating of students in the education system. They tackled the issue of cheating in colleges and high schools. They found that $75 \%$ of students admitted to cheating on an exam or paper. This Prime Time segment titled "Caught Cheating in School" was a six-month study of college and high school students about cheating practices and the reasons why they cheat. The research, claiming that cheating is at an all time high, was facilitated and narrated by Charlie Gibson. Of the 12,000 college students, $75 \%$ admitted that they have cheated on an exam or term project (Mujtaba and Preziosi, 2006). These students said that they know cheating is wrong, but they do it in order to be better prepared for real life in the business world where cheating and manipulating the system to "get ahead" seems to be the norm. Students are using calculators, cell phones, computers, and other devices to store and/or download relevant information to complete the exam. Many schools have wireless access to the Internet and students are fully able to use this system to download the answers and cheat very easily. One student was timed by Charlie Gibson to see how long it took her to get the answer for one of the questions from another student using her cell phone's text messaging function. It took her less than 30 seconds, using one hand under table, to ask the question and receive the answer while the other hand seemed to be attempting to take the test. Furthermore, ABC's poll concluded that $36 \%$ of high school students admitted that they had cheated and 7 out of 10 students say that their friends have cheated. Researchers on the show stated that business administration students are the top cheaters in self-reported surveys. They tend to rank first or second among the highest cheaters. Some students feel that they need to cheat since their counterparts are doing it. Others feel that they need to cheat as the school system is simply a "dress rehearsal" for the "cut throat" world of business. Many students feel that if senior business officers or religious leaders cheat and politicians, including governors and presidents, lie, then they, too, have the right to cheat and get ahead using tactics available to them. Some of the students tend to see the school system as their laboratory for experimentation and learning to manipulate employees, colleagues, and other stakeholders for their own personal gain.

Ethics consultant, Michael Josephson, stated that students feel as though it is "okay" to cheat since professors allow it. There is nothing wrong with the students since they simply think they will get behind if they do not do what they are allowed to do in order to have high performance. In a survey of 4,000 American and Canadian school educators, about 50\% stated they have ignored obvious cases of cheating. As such, adults must be aware of cheating methods, stop cheating, teach students that cheating is wrong, and tell them that cheaters will be punished. In one case, a college professor found that about a half dozen of his students had cheated from an online site where information was prepared and presented by fifth grade students. It is sad to see that college students do not have 
time to prepare their own material but rather are plagiarizing from fifth graders. They feel that they have to keep up their grade point average (GPA) since college recruiters tend to hire those with high GPAs. Some students feel they must cheat since there is too much work for them to complete in such a short period of time. However, others thought it is the fault of the teachers for not punishing those who cheat.

During one experiment, students were caught cheating by checking their papers in the "Turnitin.com" website to see how many of the submitted papers were plagiarized. "Turnitin.com" is one tool that many educators use to catch cheaters. It can scan about 15,000 papers submitted by educators every day. "Turnitin.Com" tells the faculty what is copied from other sources and what percentage of each paper is directly copied from these sources. The software marks all copied items in red and underlines them for the faculty. All this can be done in a matter of minutes based on the personal experiences of these authors and many colleagues that regularly use it.

Some students cheat because they do not think that they have the time to do a quality job in order to get a good grade. One student said that the "general student body" feels that cheating is "okay" in some cases, especially when one has several assignments that are due on the same day, which leaves little to no time to complete them all qualitatively. One of the teachers in the experiment asked her class, "How many of you would cheat if you knew that you would not get caught?" Practically all of the students raised their hands. These students were given an assignment after the discussion and about 67\% (two thirds) of the class had copied much of the material from other sources as their own without proper citation and referencing. In some cases, students had only copied a few phrases as their own while others had copied as much as $80 \%$ of the material, despite the fact that these students had seen the Robinson's Honor Code posted everywhere in their school and had a discussion on cheating during that same week. Subsequent discussions with these students showed that they felt cheating on academic assignments was a necessity for high performance and college entry. One high school student who had copied $80 \%$ of the material said he started the paper early in the evening, then ate dinner and finally helped his mother with the dishes before returning to complete the paper. At this time, it was 11:00 PM and he cheated because he did not want to stay up until 3:00 AM to complete the assignment. Another student who had also copied $80 \%$ of the assignment said he did it because he did not care much about this class and chose to spend most of his time studying for other more important subjects since he had several other exams and assignments due the same day. Such forms of cheating are not limited to high schools or two-year community colleges. Research shows that even top universities have had high rates of selfreported cheating. Michael Josephson said the higher the status of the school (such as Ivy League Schools), the more competitive the environment, the more pressure to earn higher grades, then the higher the rates of cheating will be in such environments. This is also true of the "real world" where the biggest bankers get caught cheating at the highest rates since the competition is very tough for them to do well, and that they are "bailed" out by the government (and taxpayers).

Some students hire a professional writer to write their papers at a cost of approximately $\$ 25$ each. One writer, named Andy, said that he has written over 500 papers for his "clients" who come to him mainly through word-of-mouth advertising. Andy, who sees himself as a business person and an entrepreneur, stated that, for a fee, he sometimes takes tests for students in classes or for entry exams. For papers, Andy downloads the needed material for his "client's" topic and re-writes each sentence in order to beat "Turnitin.com" and other such software. He feels as though he is helping students earn better grades while earning a regular income for expenditure in society. So, based on Andy's thinking, this is a win-win situation for all involved. Andy also writes applications and essays for students who are trying to get into medical and law schools, which tend to have higher enrollment standards than most other schools. In terms of goals, Andy, who is currently a student, wants to become a medical doctor. Other students in this discussion also stated that they are going to school to become lawyers, doctors, and senior business officers. However, Charlie Gibson stated that none of them mentioned that they are going to school to get an education.

Now, it has become easier to cheat in college with the availability of carry-on technologies such as calculators, IPAQs, cell phones, and two-way pagers. It was extremely easy for the students to cheat through these mediums. One of the students said, "Cheating in college prepares you for the cut-throat business practices of the real world." They consider it a "dress rehearsal for life." Of course, many educators are stunned to hear this mindset with America's youth. It is not like these are just one in a million. These students figure if they are getting a lower grade 
when they study, they might as well cheat. They have lost the integrity of actually studying to learn, regardless of how much time it takes to understand the concepts. The high school and college students had the same attitude. The only difference was their motivation: the high school students needed acceptable or competitive grades to get into college and, for many of these students, it did not matter how they obtained the grades.

It appalls most educators, to say the least, to know that higher-level students would actually steal words from fifth-graders. That does not say too much for the educational system, does it? There is another site on the web (www.cheathouse) that houses term papers, essays, and book reports for high school and college students. There are several more sites that students seem to come across in assisting them to prepare papers. These sites are such that one can easily buy an essay or report whenever needed. Furthermore, some sites even promise that they have not been plagiarized! It is just a sad state of the world when students place no faith in themselves to do their own research and write their own papers or they are just too lazy to do it. Perhaps, it just goes to show that many individuals with these upper-level careers do not even belong there if they got ahead using such tactics.

Accordingly, it causes one to wonder what ethics is all about. People are reading about business ethics to discover the differences in the value of today's population. There seems to be a segment of the population (students or senior officers of large corporations) that will take the "low road" in every case regardless of the cost or the means. Cheating seems to be similar to a computer virus and worms that mess up programs and hinder productivity. Obviously, we are working from a deficit in leaders with character and integrity. How can we change our leaders, too?

Back in the "old days" when most of today's educators went to college, there were papers for sale. Some of the campus groups maintained a file for the members to use for various classes. There were people who wrote papers for a price. Yes, there may always be individuals in the population that will try a short cut in every case, but their numbers seem to be increasing with the wide usage and availability of cyberspace technology. Technology and the internet can be a good and a bad thing in terms of their usage when people do not think about their actions and morals. People have to hold onto their morals, thus think about their values when they are faced with such temptations, since these urges for "short cuts" do not end during one's commencement or graduation.

While cheating goes on and is becoming part of the norm for some students, there is another dilemma or trend where some students who have great potential are not even going to class or doing homework. At times, teachers are not making the necessary inquiries or setting up parent/teacher conferences, and the students are suffering. The students know "right from wrong" and have often taken responsibility for their actions...to a point. However, it is the adult's responsibility to point out their shortcomings to these students. One educator, let's call him Sam, said "One student that fits this mold is labeled a "troublemaker" by everyone but me. I recognize he has behavior issues in class which seems to be due to the fact he has limited reading skills (this was assessed privately) and he or she is acting out. What a mess and it is getting worse." So, how do schools turn this cheating phenomenon that is becoming a huge problem around before it gets out of hand? Turning this around must start with adults and senior business role models by not cheating stockholders and investors out of their hard earned incomes. These senior officers and political role models must become model citizens by having fair accounting practices and by promoting integrity and honor which are not separate entities from the practice of doing business and getting ahead. Furthermore, as Mahatma Gandhi once stated, "These role models in society must become the change they would like to see in others."

Most people tend to agree with the solution of the "zero tolerance" policy while modeling expected behaviors and believing that it can work. However, many also believe that it is unlikely to happen on the scale necessary to make a major impact on reducing the level of cheating in schools any time soon. The reasoning stems from witnessing an adult population in schools which has become complacent and as a result, lets students do almost anything but fight one another in their vicinity. It is as if the attitude is, "They are not trying to kill me or each other, so their behavior is ok, and besides I don't need any more hassles." The adults have let the atmosphere deteriorate into this state, so it is going to be very difficult to rely on them to revive the culture to a new and improved state. Many individuals know we do not have many choices but to rely on adults to lead and children to comply, which might be the best alternative to the current challenge. Administrators, faculty, and staff have the power to create and cultivate any atmosphere they "collectively" choose to implement. In some districts, leaders are looked upon with 
skepticism and distrust where people do not always trust one another wholeheartedly. There is the widespread "us vs. them" mentality reinforcing the dichotomy where people relieve themselves of the responsibility to fix the problem. There are still racial issues and concerns about unfair treatment of minorities and females that educators and employers must overcome as well. There is no "quick fix," no panaceas or easy answers for such complex challenges facing the community. However, most people agree and believe that the adults are just as responsible for the attitudes and behaviors as the students themselves. Once everyone recognizes this responsibility, then there may be hope for all educators, administrators, and students on internalizing a commitment for change.

\section{WHY DO STUDENTS CHEAT?}

Is it that students are morally deficient? Do they have ethical and moral problems? Do they lack moral development? Do they lack an understanding of the ethics of cheating? Do they not understand that cheating is morally wrong? Perhaps it is a result of ethical relativism; that is, of differing moral standards based on culture. For example, there are differing societal and cultural conceptions as to ownership of intellectual property. Maybe the old saying "imitation is the sincerest form of flattery" is true. Of course, then one can argue, as the authors of this essay will, and forcefully so, that there are universal and absolute moral values which are true and valid for all people and all times. Those values mean that it is wrong to lie, cheat, and steal - period.

Granted, today there is a highly competitive and intense academic environment - from high school to college to graduate, law, and medical schools - as well as an intense pressure to excel from peers, parents, and employers. There is also a highly competitive business environment, exacerbated by today's deteriorating economy, shrinking job market, and concomitant very heavy pressures for higher sales, profits, and stock prices.

One insidious factor leading to cheating is the perception that "everyone is doing it", not only in the academic environment, but also in the business and political realms; and this cynical feeling can be worsened considerably by the perception that a school is not serious about preventing and punishing academic misconduct.

Is "ignorance an excuse"? That is, is there a lack of the requisite knowledge and skills needed to make the "right" decision? Did the students not think the conduct was cheating? Did they not even stop to think about it at all? Perhaps they did not think that cheating was necessarily wrong. Maybe they are confused about what is meant by cheating and plagiarism. For example, when is information taken off Internet research and when is it plagiarism? Where is the line between teamwork and collusion? The rules and standards of the school and/or the faculty members may not be clear, especially in a school, such as the authors', that emphasizes teamwork and collegiality. What if the school has graduate and undergraduate divisions? Should graduate students be held to a higher standard? Should graduate students have a better understanding of plagiarism and proper citation? One would think so, but the authors would counsel not to assume that any students know the proper methods of citation. Moreover, even if they are educated in this regard, there is the problem of sloppy scholarship; that is, "rushed" scholarship - especially from adult working students - resulting in perhaps inadvertent honest mistakes. To illustrate, the academic honesty policy at the authors' school makes a distinction between deliberate and accidental plagiarism, with the former, of course, resulting in more harsh sanctions. Thus, it is always best to declare, loudly and firmly, to the students, "when in doubt, provide a citation!"

Technology, as mentioned, certainly has made cheating more opportunistic for the students. Academic misconduct, cheating, and fraud never have been easier due to Internet and advanced technology (such as email, cell phones, pagers, "paper mills" and term paper websites with papers, exams, and essays for sale - and usually with a "for research purposes only" disclaimer, "thanks" to the lawyers - online courses with chat rooms). Therefore, technology provides many, and perhaps too tempting, opportunities to cheat. It is very easy to abuse technology in the classroom and otherwise.

Another factor that may lead to cheating is short-term, erroneous thinking on the part of the students. That is, the erroneous view that getting the diploma is more important than acquiring the knowledge. Consequently, the students may not realize that cheating devalues learning, and therefore the students are only cheating themselves. 
A serious problem that can lead to or exacerbate cheating is a "mixed message" syndrome emanating from schools and faculty members. Any confusion or lack of certitude as to what constitutes misconduct, cheating, plagiarism - whether it will be punished or whether it will be punished in an appropriate and consistent manner - is bound to cause problems. If the students feel that cheating will result in a mere slap on the wrist, or whether there will be any sanctions at all, such a message will indicate to the students that misconduct is acceptable. Also, confusion can be caused by schools and faculty as to what constitutes appropriate collaboration and teamwork and improper collusion.

Another factor - and a sad one - that can engender cheating is low self-esteem on the part of some students. That is; there may be, in an unfortunate case, a lack of confidence by a student that he or she cannot adequately do work without cheating. Hopefully, a perceptive and concerned professor will be aware of such a student and will work with him or her to make sure that he or she has the necessary knowledge and skills to master the class materials. Also, the professor might consider allowing the students to work in teams or groups, since teamwork can be a good learning tool as well as a psychological re-enforcer. Teamwork also prepares students for the teamoriented workforce of today's business world. Yet, again, the authors of this essay would emphasize that the faculty be very clear as to the extent of permissible collaboration in the work of group or team work.

What is the extent of cheating? The scholarly research and literature, as well as the popular news, suggest that students do cheat, that cheating is on the rise, and that business students may cheat the most. The authors of this essay naturally hope that the readers encounter only isolated instances of cheating at their schools. There is, of course, a growing body of scholarly research on the subject, and the purpose of this essay is not to explicate this research. Yet, according to a 2008 study by Shelly McGill, published in the Journal of Legal Studies Education, cheating is rampant in academia and is most prevalent by business students. One point, which regrettably should be evident is that in today's environment - business and academic - it is not realistic to assume that students do not engage in academic misconduct.

There are, therefore, many questions, issues, and challenges presented by academic misconduct at a college or university; but some points are very clear to the authors of this essay. The most effective way to prevent cheating is to actively promote academic integrity and, at the same time, effectively confront students who do cheat. A school must create a culture or climate that promotes the values of ethics, integrity, and academic honesty, as well as one that discourages academic dishonesty and misconduct. The goal is to take a comprehensive approach to academic honesty; that is, to promulgate a policy and to publicize, inculcate, and implement the policy. Accordingly, a school must establish a culture that discourages and deters academic misconduct. Cheating, the authors believe, should be less prolific if the culture of an institution clearly condemns such misbehavior.

The faculty members of a school are the most critical element in securing success of any academic honesty program. The faculty must reflect, uphold, communicate, and enforce the school's values and commitment to ethics and integrity. In addition, it is absolutely imperative that the faculty members are told they have, and in fact do have, the total support of their colleagues, the administration, and the deans of the school in upholding the school's policy of academic honesty ethics, and integrity.

\section{HUIZENGA SCHOOL POLICY AND CONFERENCE ON ACADEMIC HONESTY}

The authors of this essay are faculty members at The H. Wayne Huizenga School of Business and Entrepreneurship of Nova Southeastern University in Ft. Lauderdale, Florida. Their school, of course, has always had a strong commitment to ethics and, as a matter of fact, the business school was one of the first in the country, some 20 years ago, to introduce ethics as a discrete subject matter into the business student's education. Concomitantly, the school has always had a policy on, and commitment to, academic honesty. Recently, however, the school felt it was necessary to revise and strengthen its policy due to the number of instances of student cheating, exacerbated by technology, reported by their faculty members and faculty at various universities throughout the United States. 
It is, as noted, not the intent of the authors of this essay to explicate in detail the substance of their school's policy, yet, nonetheless, some fundamental points must be made. The new policy has more substance and detail. Why? The school believed that it was necessary to provide more substance and detail in order to help the faculty to teach the students what constitutes academic misconduct. Therefore, definitions of plagiarism were provided. A distinction between deliberate and accidental plagiarism was made. Definitions of the preceding two terms were also provided. The definition of "deliberate" plagiarism was broadened to "students purchasing and sharing exam answers, as well as sharing and using instructor materials". Several guidelines were offered to help the faculty and the students to determine what are proper citation methods and what is plagiarism. Cheating by plagiarism and cheating by other dishonest means were distinguished. Several examples of cheating were described. The penalties part of the policy was based on the aforementioned critical distinction between deliberate v. accidental plagiarism, with the former resulting in a sanction of expulsion and the latter (also called in the policy "sloppy scholarship") resulting in the sanction of a failure in the assignment or a failure in the course, as determined by the professor (subject to an appeal, of course). Also, a section called "disruption to the academic process" was included to cover misconduct beyond cheating and plagiarism. Significantly, a change was made in the policy to say that instead of the professor having the authority to deal with these academic misconduct matters, the professor now has the responsibility to deal with, as well as to document them, in order to enforce the rules in hopes of reducing such behaviors in the future.

It is very important to note that the school's policy was originally titled "Academic Misconduct", but the title was changed to "Academic Honesty." This change was made to emphasize the positive, educative, and inspirational nature of the school's policy and also to help create a culture and climate at the school that promotes and upholds the values of honesty and integrity. A preamble to the policy was inserted, stressing the academic honesty culture theme. Significantly, a statement was included that a violation of the policy would be construed by the school that the student no longer desired to fully participate in the school's culture of ethics, honesty, and integrity.

The revised policy is now part of every syllabus and also in Academic Policies link in WebCT online programs. It was further recommended to the faculty that the policy should also a Course Resources component of the WebCT online courses as a separate and distinct link. The goal, of course, was to make the faculty and the students keenly aware of the new policy.

\section{Huizenga School's Conference on Academy Honesty and Integrity}

In September 27, 2008, the H. Wayne Huizenga School of Business and Entrepreneurship of Nova Southeastern University conducted its yearly faculty conference with approximately 200 full-time and adjunct faculty members attending. As noted, the topic of academic honesty and integrity was the major academic focus of the conference. Nevertheless, the conference was not intended as a "Committee of 200" to rewrite the school's policies and procedures; rather, the input of the conferees was solicited as well as suggestions on how to improve the school's policies, practices, and procedures. Recommendations were requested as to how to better formulate and apply the policies, yet the overarching goal of the conference was to help underscore the school's values and to establish the school's culture of academic honesty and integrity. The presenters generally spoke on the awareness of the problem, the school policy, practical steps to detect and combat academic misconduct, as well as the school's procedures for resolving misconduct allegations. The conference was not meant to be a traditional research conference panel/presentation, though the presenters did present research results on the extent of cheating in academia. Moreover, faculty attendees were asked to share research results they had obtained or were familiar with. The objective was to engage in a free and full discussion of this very important issue, and to gain the knowledge, insights, and wisdom of all the school's faculty and administrators on this very important academic matter.

The academic honesty component of the faculty conference was conducted in the form of a panel presentation. It is important to note that due to the time constraints (the academic honesty segment of the conference was limited to two and one-half hours), as well as the fact that the panel presentations were naturally interrelated, the Moderator asked that the four presentations be conducted first, and then the conference would be opened up to questions, suggestions, recommendations, problems encountered, and solutions offered. The conference attendees 
were given four handouts: the school's Vision-Mission-Philosophy-Principles statement, the school's Academic Misconduct policy, the school's revised Academic Honesty policy, and the school's procedure statement for resolving allegations of academic dishonesty. The attendees also were given copies of the handouts of the presentations. The panel was commenced by the deans of the school. It was thought to be very important that the high-level administration of the school initiate the panel presentation and discussion so as to emphasize the importance of the subject matter, as well as the school's commitment to its values and principles of honesty, ethics, and integrity. The basic outline of the panel presentation is as follows:

- $\quad$ Welcome by Associate Dean - Dr. Preston Jones

- $\quad$ Introductory Comments by Dean - Dr. Randolph Pohlman

- $\quad$ Introductory Comments by Panel Moderator - Dr. Frank Cavico

- $\quad$ Presentations (four) - Dr. Cynthia Ruppel, Dr. Leslie Tworoger, Dr. Karen McKenzie, and Mr. Steve Harvey (Assistant Dean)

- $\quad$ Questions and Comments from Audience (at end of all four presentations)

- $\quad$ Concluding Comments by Moderator - Dr. Frank Cavico.

The Moderator also suggested that the topic of academic honesty be put forth as an agenda item for each breakout session and that discussions of these issues continue throughout the conference.

The Moderator to the academic honesty part of the conference made some initial comments and introduced the presenters. The moderator (who is one of the co-authors of this essay) related the history of the school regarding ethics, ethics education, and the school's policies of, and commitment to, academic honesty and integrity. The moderator also highlighted the changes made in the school's revised academic honesty policy. There, then, were four topics and presenters at the conference:

\section{Problem Awareness and Professional Responsibility}

Dr. Cynthia Ruppel (Professor of Information Sciences) focused on academic dishonesty; that is, plagiarism, cheating, and misconduct; how they occur; the latest tactics used by students; and what faculty can and should do to detect and deter academic misconduct. She provided and showed videos and websites made by students in which they showed - in a very exact, precise, thorough, crafty, and most disturbing manner - how to cheat. Dr. Ruppel also reported on research that indicated six out of ten students cheat. She expressed her concern that a "cheating culture" was being established.

\section{Detection Tools}

Dr. Leslie Tworoger (Professor of Management) discussed technological tools and search engines that the faculty can use to detect plagiarism, such as Turnitin.com, Google Scholar, Google Advanced Search, as well as other matching databases. She also emphasized the "professor's gut"; that is, when something does not look, sound, or feel right (i.e., when a writing style does not appear to be the student's writing style). She offered a suggestion that a professor could ban any Internet sites for research aside from the traditional .gov and org ones.

\section{Deterrence Policies and Practices}

Dr. Karen McKenzie (Professor of Accounting) discussed the practical steps and technology that faculty can take to deter academic dishonesty. Examples were provided; to wit, a signed honor pledge by students, which is a verification by the students as to receipt of the policy and/or a Certificate of Authenticity, communicating the academic honesty policy and the school's statement of policy enforcement; using a quiz on the academic honesty policy, including specifics on penalties; setting clear standards for assignments; and setting an ethical "tone" at the beginning of class. Dr. McKenzie gave one very practical and easy way to deter cheating; that is, to place the words "Version A" (or B, C, etc.) on exams, even if the exams are not different versions. Of course, she also stressed that the faculty should have more than one version of an exam. She concluded by underscoring that cheating really only cheapens and devalues the students' degree and that the students must be made clearly cognizant of this key fact. 


\section{Disciplinary Process}

Assistant Dean Steve Harvey discussed the procedural process that the school utilizes for resolving allegations of academic misconduct. He stressed that there is student representation on the school's appeal panel. He related some positive experiences that certain faculty members have had in resolving allegations of academic misconduct at the school. He took a reassuring tone and, critically, he reaffirmed the support of the administration of the school to the faculty in their efforts to uphold and enforce the school's policy.

The presentations at the conference and the questions and comments by the attendees thereafter raised many important issues which the authors tried to summarize in the following parts of their essay.

\section{SUGGESTIONS FOR PREVENTING ACADEMIC MISCONDUCT}

It is apparent that most students will do their own work as hiring others to complete their assignments goes against their personal and professional values. Nonetheless, the small percentage of students that are tempted to cheat should be discouraged and prevented from doing so in order to make the evaluation process fair for everyone. One best solution for the prevention of cheating, and to catch cheaters, seems to be the process of getting to know one's students and monitoring their progress over the entire term. In the mean time, educators can look for the clues to detect plagiarism. As you read the papers, look for internal evidence that may indicate plagiarism. According to Harris (2004), among the clues are as follows:

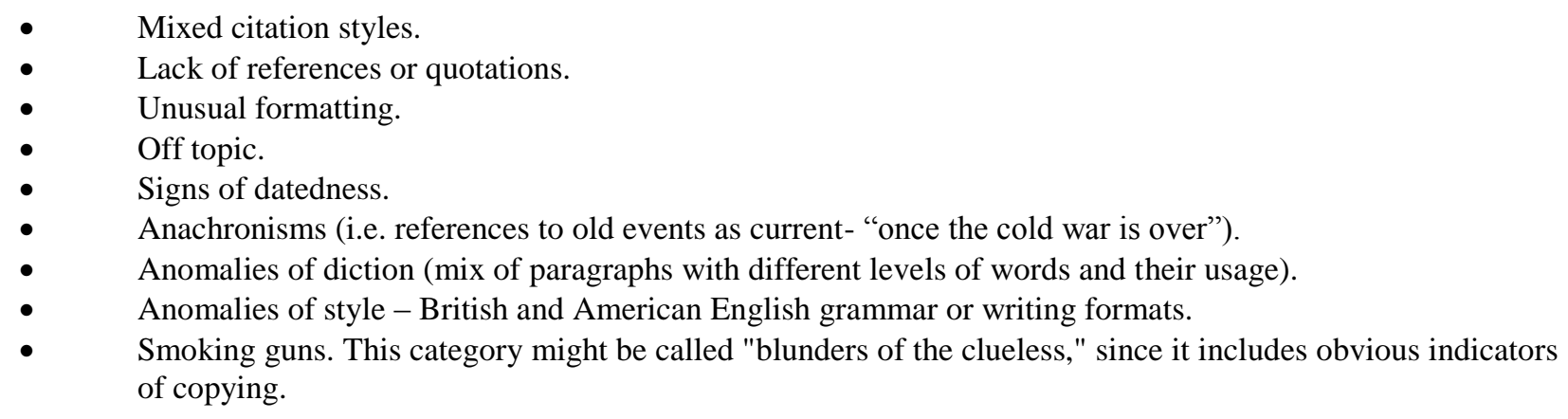

Furthermore, Robert Harris (2004) offers the following strategies and information for awareness, prevention, and detection of plagiarism:

- Understand why students cheat. By understanding some of the reasons students are tempted to cheat on papers or exams, you can take steps to prevent cheating by attacking the causes.

- $\quad$ Educate yourself about plagiarism. Plagiarism on research papers and online exams takes many forms.

- Educate students about plagiarism, its consequences and conditioning impact. What if everyone in the world cheated?

- $\quad$ Discuss the benefits of citing sources appropriately as per the school's requirements.

- $\quad$ Make the penalties clear to all students at the beginning of each class.

One simple way for faculty members to prevent or reduce the temptation for cheating is to involve students in the learning process. While most traditional faculty members focus on evaluating the cognitive domain (student's acquisition of and use of information), online educators should also focus on the affective (students attitudes, satisfaction, and perceptions of the online environment) and psychomotor (learning patterns, behavioral patterns of studying for tests, means of interacting with team members, the frequency of accessing online material in the class, etc.) domains (Tallent-Runnels et al., 2005). So, the key to making sure that students are doing their work comes down to involving students in the learning process, asking them to share their feelings about it, and helping them to integrate the knowledge into their daily routines. In other words, faculty members should involve their students' 
heads, hearts, and habits in the learning process in order to better evaluate their progress and increase their learning, thereby reducing students' temptation to cheat.

According to Tallent-Runnels et al. (2005), faculty members who teach online should do the following so that their classes can be productive for students, thereby reducing or eliminating the need for learners to cheat:

- $\quad$ Provide helpful resources on the course website that students can use to reflect upon for completion of their coursework and term projects.

- $\quad$ Let students have control over their pace at which they move through the course.

- Have lots of continuous, timely and focused discussions each week to monitor their learning.

- $\quad$ Provide timely feedback to students on their progress and performance each week.

- Make sure that the program office or school has adequate and competent technical support available for students (and faculty members who need it).

- $\quad$ Provide relevant study aids for online students. Do not always offer the same materials that are offered to traditional students for online students as it may not always be effective in other formats. Make sure that the study aids are appropriate learning tools for online students.

- Offer various forms of assignments for reinforcement so that students can better demonstrate their acquired knowledge.

Researchers Ridley and Husband (1998), by comparing the GPA of online and on-ground students, found that students' grade point averages (GPA's) were higher in the on-ground courses when compared to students in the online courses and thereby concluded that "concerns over academic integrity was either exaggerated or unfounded" (Tallent-Runnels et al., 2005). Tallent-Runnels summarize that most effective online faculty members tend to use "multiple criteria" in their assessment and evaluation of students' learning which can lead to a reduction of cheating in the virtual classroom.

There are many other things that faculty members and their institutions can do. So, what can schools do? They can stress the importance of ethics and integrity and they can stress the ethical development of the students as an educational goal. Schools can promulgate honor codes; academic integrity policies and procedures; publicize honor codes; enforce them regularly and uniformly with real penalties; make students sign a pledge (received code and not cheat); discuss honor code, ethics, and integrity from the outset (i.e., student orientation, as well as in class with professors and in printed and online material). What else can schools do? Understand why students cheat. What more can schools do? They can require ethics education programs for all students, especially for students who engage in misconduct.

What can professors do next? Ethics is the key, the authors believe. The faculty can, and must, underscore the value of morality, ethics, integrity, and professionalism. They can emphasize intellectual responsibility; the faculty can stress the long-term egoistic benefits of acting ethically; they can underscore academic integrity and honor codes from the beginning; they can emphasize that misconduct will not be tolerated; and they can make the students understand the negative consequences of their misbehavior.

What else can professors do? They can do what they are fundamentally supposed to do; that is, educate. Specifically, they can define and explain acceptable v. unacceptable behaviors; they can discuss and explain cheating, plagiarism, and the proper methods of research and citation. As part of their education responsibility, the faculty can emphasize learning; that is, professors can, and must, underscore the instrumental, as well as intrinsic, value of learning and knowledge as the primary means to the students' success. The objective is to make the students see the value of learning and to care about learning so that they might be less likely to cheat as they will just be cheating themselves.

Technology naturally emerges as an important issue in the academic honesty debate (Clark, 2008). Is technology the problem or is it the solution? As an example of technology, a solution to academic dishonesty can be the new online detection systems (i.e., Turnitin.com) that search for matching sentences, passages, and sections in students' work. To some extent, and on a smaller scale, the same can be done on Google's search engine. Could it 
perhaps be that the technology "balance of power" is changing in favor of faculty? Of course, professors always have had control of their classrooms, including the technology component; thus, professors can restrict and ban technology from the classroom.

What else can professors do? They can practically create new assignments and different exams for each section of the course; they can use multiple and differing versions of tests, as well as computer randomized versions; they can use paper assignments that cannot merely be pulled off the Internet; professors can make assignments, especially writing ones, very specific so that they are difficult to plagiarize; they can avoid using tests and assignments that make cheating easy; and, very basically, they should not leave the classroom during the exams.

A school and a faculty member must decide on differentiating serious v. minor academic violations; that is, should there be a distinction between intentional v. negligent misconduct or one between plagiarism and mere misuse? The authors of this essay believe that plagiarism can include both intentional/deliberate and negligent/accidental. Both are subject to penalties, but the purposeful type of plagiarism is subject to more harsh penalties. There are many other difficult questions to answer, including but not limited to:

1. Should students be allowed to collaborate more or less on papers and exams? Is collaboration good team training, or is it too tempting of a vehicle for cheating?

2. How severe should the sanctions and penalties be for academic misconduct? Should a sanction be a "onestrike-and-out" determination; that is, expulsion or an " $\mathrm{F}$ " in the course, or merely an "F" for the assignment? How much discretion should the faculty members have? For such cheating, should a notation concerning academic dishonesty be made on a transcript (e.g., "XF")? Should a prospective employer be notified? Should state Bar Associations and CPA exam authorities be notified?

3. What about due process protections for students? How extensive should they be? Should there be student involvement in procedures? Should there be a student "honor court"? Should students be the sole judges on such a panel? One point is clear, of course; that is, a school's policies and procedures for resolving allegations of academic misconduct must be applied fairly, consistently, and in a manner that upholds the principles of fundamental due process.

4. Should there be ethics counseling or seminars on academic integrity and honesty? Should these ethics education experiences be for students who have been found guilty of misconduct? Should they be for all students? If for all students, maybe the seminar could be an introductory one to the school and the student's future course of study in which the school's policy on academic honesty would be a primary component. Perhaps the seminar for a student deemed to have violated the school's policy could be in the form of a non-credit class (for which student pays) on academic honesty; that is, how to do research, cite sources, use the library, etc., as well as academic misconduct (plagiarism, cheating and why it is wrong and harmful).

5. Whistle-blowing is always a contentious issue. Should schools and professors mandate that students report offenders? Should students be held accountable for not reporting incidences of academic misconduct?

6. Is cheating a way of life for students who cheat? Will they cheat on their resumes? Will cheating students cheat as adults at work and in their professional lives? Is cheating in school indicative of future unethical behavior in business and the professions?

7. What about the consequences of cheating in an ethics class? Should this be a more egregious offense? Should there be more harsh sanctions? Or is cheating "cheating" regardless of the class?

8. Should there be a form to document academic dishonesty? Such a form will help to identify repeat offenders as well as provide documentation for a violation.

The authors concede that there are no easy answers to the aforementioned questions, yet their hope is that the "reflections" will enable faculty members and their schools to more fairly, intelligently, and efficaciously resolve these important academic issues.

\section{SUMMARY}

The faculty and administration of schools cannot abdicate their responsibility; they cannot look the other way; they cannot tolerate cheating; and they cannot make cheating easy. The faculty must make sure that students 
are educated as to academic honesty and misconduct; the faculty should not assume that students have received the knowledge and training elsewhere; and the students must be trained on how and why to avoid plagiarism and cheating. Another principal duty of the faculty is to educate the students as to ethical standards and practices and the faculty must inform the students, clearly and firmly, that they are doing something "wrong." Such a moral lesson will hopefully affect the students' conscience and moral sense. So, by all means let the students know what cheating is and why it is wrong, and also let the students know - all the time - that cheating will not be tolerated. Furthermore, be a learner-centered educator and try to do the following to reduce a student's need for cheating:

- $\quad$ Gain and focus attention on learning outcomes.

- Inform learners of the expected outcome (first session through the course syllabus and discussion).

- $\quad$ Stimulate recall of relevant prerequisites.

- $\quad$ Present new material through lectures and/or facilitation.

- $\quad$ Offer guidance for learning and application.

- $\quad$ Fairly assess the students' performance for improvement.

- Make transferability possible through application and discussion of experience. Allow for self-assessment.

- Ensure content retention by exposing students to the same material several times (6) during the term/semester.

- $\quad$ Provide qualitative and timely feedback each week.

The authors firmly believe that the most effective way to prevent cheating is to facilitate effectively as a learner-centered educator, while actively promoting academic integrity and, at same time, to effectively confront students who do cheat; that is, a school must create a culture and a climate that promotes the values of ethics, integrity, and academic honesty, as well as a culture and climate that discourage academic dishonesty and misconduct. Thus, a school must take a comprehensive approach, consisting of promulgating an honor code and publicizing and implementing the honor code, as well as involving the entire institution - students, faculty, and administration - in these important initiatives. A school must establish a culture that discourages academic misconduct; cheating should be less prolific if the culture of a school clearly condemns such misbehavior. Yet the tone of these honesty efforts should be an inspirational one. Faculty members are the most critical element in securing the success of such an academic honesty program. The authors assert that it is absolutely imperative that the faculty reflect, uphold, communicate, and enforce the school's values of and commitment to the values of honesty, ethics and integrity. Perhaps a great place to begin the initiatives on the reduction and prevention of cheating is to collectively reflect and agree upon answers to such questions as the following:

1. What is cheating? Discuss specific examples of what is considered cheating.

2. Is cheating limited only to university students or does it begin with high school students and move on to business people? Discuss examples.

3. What are some common methods, techniques, and/or strategies that students use to cheat in the classroom?

4. What are some common methods, techniques, and/or strategies that business people use to cheat in the workplace?

5. What can students, faculty members, and administrators do to prevent cheating in the academic environment?

\section{AUTHOR INFORMATION}

Bahaudin G. Mujtaba, D.B.A., is currently a Department Chair and an Associate Professor of Management and Human Resources Management. Bahaudin was given the prestigious annual "Faculty of the Year Award" for the 2005 Academic Year at Nova Southeastern University's H. Wayne Huizenga School of Business and Entrepreneurship. Bahaudin has served as manager, trainer and management development specialist in the corporate world as well as a director, department chair and faculty member in academia. His areas of research are ethics, higher education assessment, leadership, faculty training, and diversity management. 
Frank J. Cavico is a professor of Business Law and Ethics at the H. Wayne Huizenga School of Business and Entrepreneurship of Nova Southeastern University. In 2000, he was awarded the Excellence in Teaching Award by the Huizenga School. In 2006, he was honored as Professor of the Year by the Huizenga School. Professor Cavico holds a J.D. degree from St. Mary's University School of Law and a B.A. from Gettysburg College. He also possesses a Master of Laws degree from the University of San Diego School of Law and a Master's degree in Political Science from Drew University. Professor Cavico is licensed to practice law in the states of Florida and Texas. He has worked as a federal government regulatory attorney and as counsel for a labor union; and has practiced general civil law and immigration law in South Florida.

\section{REFERENCES}

1. $\quad$ ABC Prime Time News, (2004). Cheating in Schools. April $29^{\text {th }} 2004$.

2. Clark, Kim (2008). Taking a bite out of cheating, with the thelp of technology. U.S. News and World Report, October 13 / October 20, pp. 74-76.

3. Harris, Robert (November 2004). Anti-Plagiarism Strategies for Research Papers. Retrieved on 03/29/2006 from: http://www.virtualsalt.com/antiplag.htm

4. McGill, Shelly (2008). Integrating Academic Integrity Education with the Business Law Course: Why and How? Journal of Legal Studies Education, 25 (2), pp. 241-82 (Summer/Fall).

5. Mujtaba, G. B. and Preziosi, R. (June 2006). Adult Education in Academia: Recruiting and Retaining Extraordinary Facilitators of learning, $2^{\text {nd }}$ ed. ISBN: 1-59311-476-1. Information Age Publishing. Greenwich, Connecticut. Phone: (203) 661-7602.

6. O'Keefe, Brendan (2005). One in six cheated in an online exam. Higher Education; p.27; December 7, 2005; All-round Country Edition.

7. Ridley, D. R., and Husband, J. E. (1998). Online Education: A study of academic rigor and integrity. Journal of Instructional Psychology, 25, pp. 184-188.

8. Tallent-Runnels, M. K.; Cooper, S.; Lan, W. Y.; Thomas, J. A.; and Busby, C., (2005). How to Teach Online: What the Research Says. Distance Learning, 2(1), pp. 21-27. 
NOTES 